\title{
THE DEVELOPMENT OF MATHEMATICS TEACHING MEDIA BASED ON IAI
}

\author{
Elvi Mailani, Akden Simanihuruk, Imelda Free Unita Manurung \\ Elementary School Teacher Education, faculty of Science Education, Universitas Negeri Medan, Medan, Indonesia \\ *Corresponding Author: elvimailani@gmail.com
}

\begin{abstract}
The aim of this research is to develop a media for learning mathematics in elementary school based on Interactive Audio Instruction (IAI) for students majoring in UNIMED elementary school teacher education. The IAI-based fraction media was compiled based on observations during the learning and analysis conducted on the dictates of high-class mathematics education courses and interviews conducted with elementary school teacher education students, where teachers were very difficult to convey material related to fractions, The teacher does not know what media to use in teaching broken material. On the other hand, in the high school mathematics education textbook, there is also no media I teaching aids that can be used to teach fractional material. The specific purpose of this research is: developing IAI-based fraction media which will later be used by students majoring in primary school teacher education in teaching fraction material when they later become a teacher. This research uses development research (Developmental Research). The subjects of this study were students majoring in primary school teacher education at the State University of Medan. In the initial stage, observations were made during the learning process, analysis of the dictates of high-level mathematics education courses and continued with interviews with students. From the results of these observations and interviews, an initial draft of the IAI-based fraction was compiled. Furthermore, the initial design of the IAI-based fraction media was validated by a team that aimed to assess the quality of these elementary mathematics learning media fractions so that the fractional media became effective learning media which would later be used by lecturers and students in the lecture process.
\end{abstract}

Keywords: IAI; Fraction Media; Math Learning.

\section{INTRODUCTION}

UNIMED elementary school teacher education (PGSD) is an institution that aims to produce teachers at the elementary school level who have good educational qualifications and insights. Graduates of this elementary school teacher education are expected to become teachers who have broad insights into education, as well as having various skills in carrying out the learning process in the classroom. A variety of skills are expected including: skills in designing learning, implementing learning processes using various approaches and learning models, skills in designing instructional media and skills in carrying out evaluation of learning.

"2013 Thematic Learning Curriculum called integrative thematic learning has a different approach to thematic learning in the previous curriculum. The approach used to integrate the basic competencies of various subjects is intradisciplinary, interdisciplinary, multidisciplinary, and transdisciplinary" (Diputra: 2016). According to Sri Muryaningsih (2015: 193) that "thematic learning is learning that utilizes themes in the delivery of material. The theme acts as a unifying learning activity that integrates several subjects at the same time by choosing a theme that can unite indicators of several elementary subjects. Elementary school subjects that can be taught using thematic learning are: Religious Education, Civic Education ( $\mathrm{PKn}$ ), Indonesian Language Education (BI), Mathematics, Natural Sciences (IPA), Social Sciences (IPS), Cultural Arts and Crafts (SBDP), and Physical Education Sport and Health (PJOK) ". However, for Mathematics and Physical Education Sports and Health (PJOK) subjects as standalone subjects for classes IV, V, and VI.

To realize this expectation, in the lecture process that was carried out at PGSD UNIMED, various activities were designed to improve the competence and skills of PGSD UNIMED students. In addition, the courses given in lectures are courses that are really needed for students if they later become teachers after completing their education in the education department of elementary school teachers. One of the courses given to UNIMED PGSD students is a highclass mathematics education course. In this high-class mathematics course, students are equipped with a variety of material and mathematical concepts related to the material: (a) arithmetic operations and counts, (b) fractions, (c) flat shapes and spaces, (d) roman numbers, (e) comparison and scale, and (f) statistical. which is indeed a matter of 
mathematics starting from class IV, V and VI at the elementary school level based on the 2013 curriculum that is used today.

"Understanding mathematical concepts and communication is a competency that must be developed in students so that they are ready to face life's problems in the future. In addition, affective competence, such as the spirit of learning, independence and perseverance is also an important capital for students in developing their full potential "(Coal: 2017). "Mathematics needs to be given to all students from elementary schools to equip students with the ability to think logically, analytically, systematically, critically, and creatively, as well as the ability to work together. These competencies are needed so that students can have the ability to obtain, manage, and use information to survive in ever-changing, uncertain, and competitive circumstances. In mathematics, a student will learn about the concept of arithmetic and is expected to be able to apply it in everyday life "(Indaryati: 2015). One of the subject matter of mathematics which is very difficult to be mastered by elementary school level students, especially fourth grade students is fractional material. This can be seen from the results of observations and interviews with a number of students, most students said it was difficult to understand the fraction material. Moreover, when working on the count operations it is addition, subtraction and division of fractions. This is because the mastery of the concept of fraction material itself is not so well mastered by students, other than that how to teach teachers is still very monotonous. In teaching fraction material, the teacher only uses the blackboard to explain how to do fraction counting operations without trying to use media or other supporting aids.

The same thing was felt by researchers as lecturers in the department of elementary school teacher education (PGSD) UNIMED, when conducting interviews and discussions with students, most students also experienced obstacles and did not have ideas and ideas on how to teach these fractional materials to students so students easily understood them . When asked what media / teaching aids can be used to facilitate students' understanding of fractional material, all students do not have ideas or ideas that can overcome these problems. This condition certainly cannot be tolerated and solutions must be sought immediately, so that the learning process, especially in fraction material, can be better and more attractive so as to make it easier for students to understand fraction material.

"That learning media is a tool or object that can be used for intermediaries to channel lesson content or material that is delivered so that students are easy to understand the material delivered by the teacher" (Asyhari, 2016). There is also an opinion which says that "Media learning is recognized as one of the factors of learning success. with the media, students can be motivated, actively involved physically and psychologically, maximize all learners' senses in learning, and make learning more meaningful (Muhibbudin: 2015). "In order for mathematics learning to be conveyed well and accepted by students, it requires the latest innovations in learning mathematics, namely by utilizing learning media in order to arouse students' desire to learn mathematics and reduce student anxiety in learning mathematics" (Maghfira Maharani: 2018).

"The reality is in the field, there are still many teachers who do not develop their creativity to plan, arrange, and develop learning media that are innovative and interesting for students. Many educators still use conventional learning media, such as whiteboards and whiteboards, or instant learning media, just buy and use directly such as wall drawings, posters and maps. This has an impact on decreasing teacher creativity and influencing students' interest in learning. It is very possible that the learning media they use are not contextual, less attractive, seem monotonous, and do not fit the needs of students "(Hengkang Bara: 2015).

Based on the description above, the problem in this study is the absence of media / teaching aids that have been used so far in teaching fractions to elementary school students, so the ability and understanding of students towards fractions is very weak. Fractional media / teaching aids are really needed by students to facilitate their understanding of fraction material. The purpose of this research is the development of elementary mathematics learning media especially for fractional material. Fractional media for elementary school mathematics learning is expected to help provide conceptual understanding of fractions to students in particular and make it easier for students to work on problems related to fraction counting operations. This is because by using this fraction media, students can see firsthand how the fraction counting operation process is found and students can implement it in the process.

\section{METHODS}

This research was conducted at the Faculty of Education (FIP), Medan State University in the department of elementary school teacher education (PGSD). The use of fractional media for primary school mathematics learning for elementary school teacher education students is to provide provisions and knowledge to students about media / teaching aids that can developed and used in teaching fractions material to elementary school level students. This research uses development research methods. Richey and Nelson (1996) identified that developmental research (Developmental research) is oriented towards product development in which the development process is described as thoroughly as possible and the final product is evaluated. 
The researcher uses six elements contained in the Van Den Akker development model, namely: (1) Preliminary analysis, (2) evaluation of experts and teachers, (3) initial fraction media model, (4) fraction media validation (5) empirical data, (6) ) reflection and revision. The sequence of development steps for the IAI-based fraction media based on the Van Den Akker research and development model can be seen from the following figure:

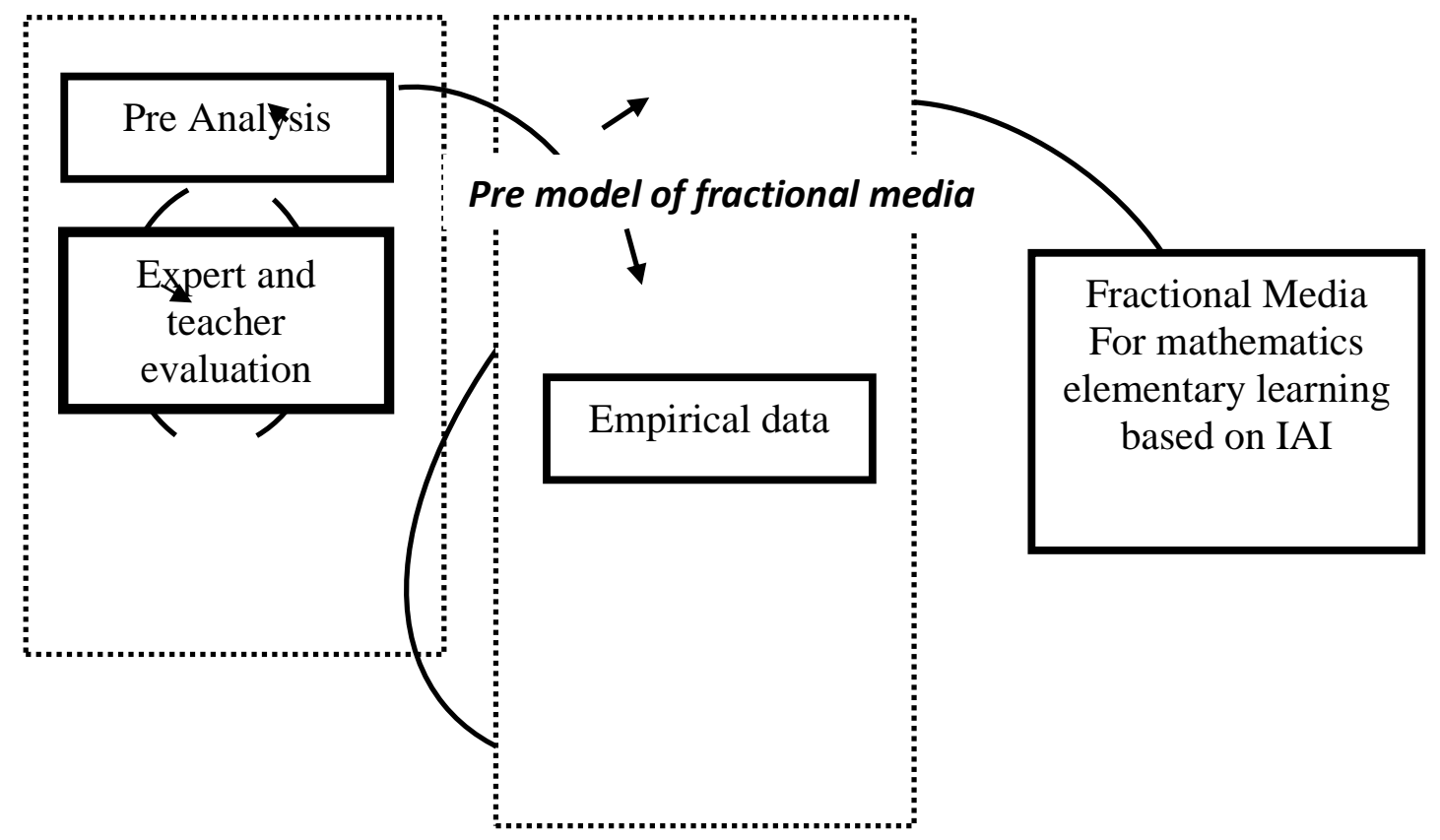

Figure 1. Diagram model of research and development by Van den Akker (1999).

\section{Device Development Stage \\ Preliminary Analysis}

The initial analysis consists of several steps that must be carried out, namely:

Purpose Analysis

The purpose of this analysis is to determine the basic direction needed in the development of elementary mathematics learning media fractions that will be used for PGSD UNIMED students as a provision for them to have completed their education and become a teacher in elementary schools. From this basic direction then compiled alternative media suitable elementary school mathematics learning fractions. In carrying out the analysis of objectives, in terms of aspects of the curriculum used at the present elementary school level.

\section{Analysis of student characteristics}

Student analysis is a study of student characteristics which include the level of cognitive development, ability, background knowledge, and socio-cultural background of students. From the results of this analysis will be used as a frame of reference in preparing elementary school mathematics learning fraction media that will be used by teachers and students so that the learning media fraction of mathematics is developed in accordance with the characteristics of elementary school students.

\section{Analysis of Teacher and Student Needs}

Analysis of teacher and student needs is a review of the main needs in the development of elementary school mathematics learning fractions. This analysis is based on experience while the teaching and learning process takes place where clearly visible obstacles felt by the teacher in providing an explanation of the concept of fraction material. On the other hand PGIM UNIMED students are also the embryo of teachers who will also teach at the elementary school level, of course, will also experience the same obstacles if they are not equipped with the ability to design and use media in learning, especially learning mathematics in fraction material.

\section{Expert and Teacher Evaluation}

Based on preliminary analysis that has been done, the fraction media was designed which will be used in overcoming the problem of elementary school mathematics learning. Expert and Teacher evaluation was carried out after the fraction of elementary school mathematics learning was completed designed by researchers. An evaluation will be carried out to see whether the fraction media designed according to the characteristics of elementary school levels, is harmless and can help teachers and students of PGSD UNIMED make it easier to provide understanding of fraction 
material, while for students whether the fraction media can facilitate understanding they are on fractional material, especially in working on fraction counting operations.

\section{Development of Early Models of Fractional Media}

The fractional media of elementary school mathematics learning developed was given the name based on IAI. The name stands for "Interactive Audio Intruction Based Fraction Operations". IAI-based fraction media are made from simple materials such as: plywood as the main container, while other materials are made of transparent plastic shaded according to the fraction to be studied, while IAI uses audio video which will later be played as a teacher's guide to understand how media use can also be used directly by IAI-based media users independently. How to use this media is quite easy, students only need to stick transparent plastic in the space provided, and students can see firsthand the concepts of addition, subtraction, multiplication and the division of two fractions.

\section{Fraction Media Validation \& Instrument Validation Arrangement}

In accordance with the research objective, which is to make elementary mathematics learning media fractions, then in this study a validation instrument will be developed that is validation to measure the quality of the and IAI fraction developed media. The preparation of a validation instrument to assess the quality of the fraction media is based on (a) the compatibility of the media with the material used (b) the ease of the media in providing students understanding of the concept of the material being studied (c) the ease of the media to be replicated. While the IAI validation instrument is based on: (a) general aspects of audio video which include: visual quality (appearance), guidance for teachers and students (LKS), audio video content containing the message to be conveyed, audio video content in accordance with the task and learning activities provided, graphics, images or other things have a good color, texture and symbol, and the costs required to produce audio video are worth the benefits. (b) aspects of accessibility of audio video media which include: video components are clarified with audio, audio video components have other alternative forms in the form of print out / printed material, and audio video media is safe to use.

After the validation instrument has been prepared, the next activity is to validate the IAI-based fraction media using the validation sheet. The validation was carried out by an expert and 3 teachers in the field of mathematics study aimed to see the effectiveness, strengths, weaknesses and other matters of the IAI-based fraction media that had been developed. The results of the validation will be used as input for improving the IAI-based fraction media so that the fraction media can be better and more effective when used by teachers and students in the classroom learning process and lectures.Empirical Data.

After the IAI-based fraction media has been validated by the validator team, the next step is to improve the IAI-based fraction media in accordance with the input of the validation team. The intended improvement is intended so that all the weaknesses of the media found based on the results of the validation can be corrected so that the IAI-based fraction media developed can make it easier for PGSD UNIMED students to learn the fraction material and develop it. After the IAI-based fraction media was repaired, a trial was carried out on the IAI-based fraction media. The IAI-based fraction media test was conducted at the faculty of education majoring in elementary school teacher education.

\section{Reflection and Revision}

Based on the results of the trials that have been conducted and the results of interviews conducted with students, a reflection and revision of the IAI-based fraction media was developed. Reflection and revision aims to correct any shortcomings of the IAI-based media before it is developed more and used in primary schools and becomes material in high-class mathematics education courses in the department of primary school teacher education.

\section{Fraction Media}

The final stage of this research is to develop IAI-based fraction media after obtaining input through validation activities, and based on the results of reflection when conducted direct trials in the faculty of education majoring in elementary school teacher education at Medan State University. The development of IAI-based fraction media was carried out and the results were used in lectures at the faculty of education majoring in elementary school teacher at Medan State University.

\section{Research Instruments}

The instruments used in this study were grouped into 2 types namely; (1) Instrument of media validation in elementary school mathematics learning fractions, (2) interviews with students after the learning process using IAI-based fraction media.

\section{RESULT AND DISCUSSION}

The results of the implementation of research activities in the development of mathematics learning media " on the ability of students can be described as follows: 
The pre-test was conducted on August 27, 2019 with the results of data obtained from 34 students, 15 students (44\%) got good grades, 10 students (29\%) in the moderate category, while the remaining 9 students $(27 \%)$ in the less category. As for the description of the acquisition of student pre test scores can be seen in the following figure:

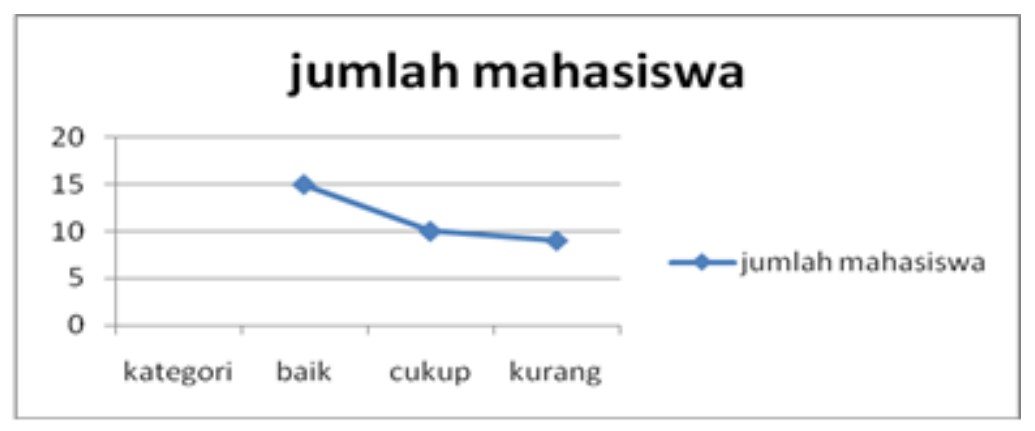

Figure 2. The result of student's pre-test.

Implementation of activities with material operations count fractions. In this activity students are invited to design a media guide ". " media are media that can be used to facilitate understanding of fraction material .. media developed in cycle II can be used to facilitate the understanding of concepts in doing fraction computations that are added, subtracted, times and divided (+, -, $\mathrm{x}$ and:).

Post test activities carried out aiming to see the usefulness of the media " in helping students understand the fraction material. The results of the post-test activities obtained data from 34 students, 29 students (85\%) scored in the good category, and the remaining 5 students (15\%) in the sufficient category, from the results of this post-test it was seen that there was an increase in the ability of students of teacher education courses elementary school (PGSD) Medan State University. The description of the acquisition of student post test scores can be seen in the following picture:

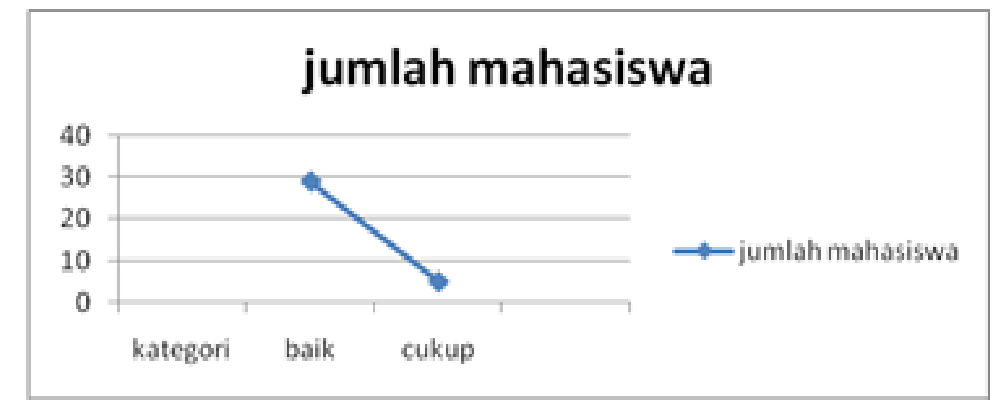

Figure 3. The result of student's post-test.

\subsection{Discussion}

The development of IAI-based learning media is proven to be able to improve the ability and understanding of PGSD students at Medan State University. This can be seen from the results of tests conducted before and after this research activity was carried out. Based on available data, it can be seen that students' ability to understand various material concepts, especially those related to fractions, becomes better. Students better understand the process of calculating fraction operations and find the concept of the arithmetic operations after using the media.

In addition to developing media, the use of the Interactive Audio Instruction CD (IAI) also feels very helpful for students in understanding the material for calculating fractions. The IAI CD can help deepen student understanding at home without having to get guidance from lecturers directly. The IAI CD that was developed can make students learn to understand the concept of fraction count operations by trying and learning them independently.

The use of media and the Interactive Audio Instruction CD are very helpful in giving students an understanding of the concept of fraction counting material. This is very useful because students majoring in elementary school teacher education (PGSD) Unimed as prospective education personnel at the elementary school level, are expected to have insight and ability in designing and developing media that can be used in instilling abstract mathematical concepts so they can help students in understanding mathematics material at elementary school level. 


\section{CONCLUSION AND SUGGESTIONS}

\subsection{Conclusion}

1) Pengembangan media pembelajaran matematika" berbasis IAI dapat menningkatkan pemahaman mahasiswa jurusan pendidikan guru sekolah dasar (PGSD) fakultas ilmu pendidikan Universitas Negeri Medan terhadap materi pecahan.

2) Buku panduan penggunaan media sangat membantu mahasiswa dalam memahami bagaimana proses dan penggunaan media " tersebut dalam memahami konsep operasi hitung pecahan yang abstrak.

3) Penggunaan CD interactive Audio Instructional ( IAI ), dapat membantu pengguna media " secara mandiri tanpa oerlu bantuan orang lain.

\subsection{Suggestions}

1) Pengembangan media pembelajaran matematika diteruskan pada materi-materi yang lain, agar pembelajaran matematika menjadi salah satu mata pelajaran yang disenangi dikalangan siswa sekolah dasar.

2) Media " yang dikembangkan diberi warna yang lebih menarik agar lebih menumbuhkan semangat penggunanya.

\section{REFERENCES}

Ardian Asyhari, H. S. (2016). Pengembangan Media Pembelajaran Berupa Buletin Dalambentuk Buku Saku Untuk Pembelajaran IPA Terpadu. Jurnal Ilmiah Pendidikan Fisika Al-BiRuNi, 1-13.

Azimi, A. R. (2017). Pengembangan Media Pembelajaran IPA Berbasis Literasi Sains untuk Siswa Sekolah Dasar. Pancasakti Science Education Journal.

Batubara, H. H. (2017). Pengembangan Media Pembelajaran Matematika berbasis Android untuk Siswa SD/MI. Muallimuna, 12-27.

Dek Ngurah Laba Laksana, I. G. (2017). Pengembangan Multimedia Pembelajaran Tematiksekolah Dasar Berbasis Budaya Lokal Masyarakat Flores. Jurnal Pendidikan Dasar Nusantara, 151-162.

Desty Triastuti, S. A. (2015). Pengembangan Media Papan Permainan Panjat Pinang. Jurnal Pendidikan, 24-26.

Dimas Qondias, E. L. (2016). Pengembangan Media Pembelajaran Tematik Berbasis Mind Maping SD Kabupaten Ngada Flores. Jurnal Pendidikan Indonesia, 176-182.

Diputra, K. (2016). Pengembangan Multimedia Pembelajaran Tematikintegratif Untuk Siswa Kelas IV Sekolah Dasar. Jurnal Pendidikan Indonesia, 125- 133.

Enang Rusnandi, H. S. (n.d.). Implementasi Augmented Reality (AR) pada PengembanganMedia Pembelajaran Pemodelan Bangun Ruang 3D untuk Siswa Sekolah Dasar. Infotech Journal, 24-31.

Fadhli, M. (2015). Pengembangan Media Pembelajaran Berbasis Video Kelas IV Sekolah Dasar. Jurnal Dimensi Pendidikan dan Pembelajaran, 24-29.

Farid Ahmadi, S.,. (2-17). Pengembangan Media Edukasi "Multimedia Indonesian Culture” (Mic) Sebagai Penguatan Pendidikan Karakter Siswa Sekolah Dasar. Jurnal Penelitian Pendidikan, 127-136.

Hengkang Bara Saputro, S. (2015). Pengembangan Media Komik Berbasis Pendidikan Karakter Pada Pembelajaran Tematik-Integratif Kelas IV SD. Jurnal Edukasia, 61-72.

Ilmawan Mustaqim, S. M. (2017). Pengembangan Media Pembelajaran Berbasis Augmented Reality. Jurnal Edukasi Elektro, 36-48.

Indaryati, J. (2015). Pengembangan Media Komik Pembelajaran Matematika Meningkatkan Motivasi Dan Prestasi Belajar Siswa Kelas V. Jurnal Prima Edukasia , 84-96.

M. Taufiq*, N. R. (2014). Pengembangan Media Pembelajaran IPA Terpadu Berkarakter Peduli Lingkungan Tema "Konservasi” Berpendekatan Science-Edutainment. Jurnal Pendidikan IPA Indonesia, 140-145.

Maghfira Maharani, N. S. (2018). Media Pembelajaran Matematika Berbasis Kartun untuk Menurunkan Kecemasan Siswa. Jurnal Matematika, 101-106.

Maryani, D. (2014). Pembuatan Media Pembelajaran Interaktif Bangun Ruang Matematika. Journal Speed, 18-24.

Maskur, R., Nofrizal, N., \& Syazali, M. (2017). Pengembangan Media Pembelajaran Matematika dengan Macromedia Flash. Al-Jabar: Jurnal Pendidikan Matematika, 8(2), 177-186.

Muyaroah, S., \& Fajartia, M. (2017). Pengembangan Media Pembelajaran Berbasis Android dengan menggunakan Aplikasi Adobe Flash CS 6 pada Mata Pelajaran Biologi. Innovative Journal of Curriculum and Educational Technology, 6(2), 22-26.

MZ, Y. (2013). Pengembangan Permainan Ular Tangga Untuk Kuis Mata Pelajaran Sains Sekolah Dasar. Jurnal Teknik, 75-84.

Rizki Oktavianti, A. W. (2014). Pengembangan Media Gayanghetum (Gambar Wayang Hewandan Tumbuhan) Dalam Pembelajaran Tematik Terintegrasi Kelas IV SD. Mimbar Sekolah Dasar, 65-70.

Sri Muryaningsih, A. M. (2015). Pengembangan RPP Tematik-Integratif Untuk Meningkatkan Karakter Kerja Keras Di Sekolah Dasar. Jurnal Prima Edukasia, 190-201.

Triwendini, M. V. (2016). Pengembangan Media Pembelajaran Tematik Papan Pizza Ilmu (Papimu) Untuk Kelas IV Sekolah Dasar (Doctoral dissertation, University of Muhammadiyah Malang).

Wahyu Nuning, H. (2016). Pengembangan Media Komik Untuk Meningkatkan Motivasi Belajar dan Keterampilan Membaca Pemahaman Siswa Kelas IV. Jurnal Prima Edukasia, 233- 242. 
Wati, U. A. (2010). Pengembangan Multimedia Pembelajaran Untuk Mata Kuliah Pembelajaran Terpadu. Jurnal Penelitian Ilmu Pendidikan.

Yulianti, V. (2013). Peran Media Pembelajaran Dalam Meningkatkan Pemahaman Siswa Pada Mata Pelajaran Fiqh (Studi Kasus Kelas X di Laboratorium Agama Man Parakan Temanggung Tahun Pelajaran 2012/2013) (Doctoral dissertation, Universitas Muhammadiyah Surakarta). 